UDC 577.113.6:577.322:543.51

\title{
Studies on interaction of oligoadenylates with proteins in vitro by MALDI-TOF mass spectrometry
} \author{
I. Ya. Dubey', Z. Yu. Tkachuk ${ }^{1}$ \\ ${ }^{1}$ Institute of Molecular Biology and Genetics, NAS of Ukraine \\ 150, Akademika Zabolotnogo Str., Kyiv, Ukraine, 03680 \\ ${ }^{2}$ Palladin Institute of Biochemistry, NAS of Ukraine \\ 9, Leontovicha Str., Kyiv, Ukraine, 01601 \\ sveta.levchenko@gmail.com
}

S. M. Levchenko ${ }^{1}$, A. V. Rebriev ${ }^{2}$, V. V. Tkachuk ${ }^{1}$, L. V. Dubey ${ }^{1}$,

\begin{abstract}
Aim. To investigate the ability of «core» 2'-5'- and 3'-5'-oligo- adenylates $(O A)$ to interact with $\alpha$-interferon-a key protein of the 2'- 5'-OAS/RNAase L system responsible for antiviral cell defense. Methods. MALDI-TOF mass spectrometry was used in the studies on protein-li-gand interactions. Results. It was shown that $2^{\prime}-5^{\prime}-A_{3}$ and its epoxy-modified analog 2'-5'- $A_{3}$-epo can bind to $\alpha$-interferon in vitro. $3^{\prime}-5$ '-triadenylate is also capable of binding to this protein. One to five ligand molecules can bind simultaneously to the molecule of $\alpha$-interferon. At the same time, all studied oligonucleotides do not bind to insulin. Con-clusions. It was established that «core» 2'-5'- and 3'-5'-triadenylates are capable of multiple interaction with $\alpha$-interferon to form stable complexes. However, they do not bind to insulin which is not involved in the 2'-5'-OAS/RNAase L system.
\end{abstract}

Keywords: oligoadenylates, insulin, $\alpha$-interferon, MALDI-TOF mass spectrometry.

Introduction. In recent years oligoriboadenylates and their analogues have been studied even more actively than ever before as they are considered to be promising compounds for the elaboration of novel antiviral, antiinflammatory and antitumor agents [1-6]. They play a key role in the mechanism of antiviral defense of the cell and are also involved in the processes of cell growth and differentiation, apoptosis, pathogenesis of diabetes, atherosclerosis, etc. Numerous works on the investigation of biological activity of 2'-5'-oligoadenylates (2-5A) demonstrate that their mechanism of antiviral activity is related to the capability of affecting the proteins of 2'-5'-oligoadenylate synthetase/endoribonuclease L system (2'-5'-OAS/RNAse L) which, in turn, leads to the elimination of viral RNA [1,7-11].

At present there are a number of investigated proteins required for the functioning of the cellular system of antiviral protection. First, this is RNAse L that cleaves single-stranded viral RNA [1, 7, 12], protein kinase R controlling the synthesis of viral proteins [13], and protein $\mathrm{Mx}$ responsible for special activity against influenza virus [14]. However, the main role in the antiviral protection is attributed to interferons, which induce the expression of genes involved in the antiviral activity of the cell, and as well are capable of independent activation by the products of the cleavage of hepatitis C virus RNA by RNAse L, as proven by recent studies of Silverman [15]. While binding to protein RIG-I, these oligoribonucleotides stimulate its ATPase activity and, consequently, that of b-interferon gene, the product of which, in turn, induces 2'-5'-oligoadenylate synthetase and the synthesis of 2-5A triphosphates.

Therefore, the hydrolysis products of viral RNA are capable of activating interferon synthesis. Still there is a question of possible ability of "core" (non-phosphorylated) $2-5 \mathrm{~A}$, as well as 3'-5'-oligoadenylates, to interact directly with interferon and thus affect its functions. 
One of the modern methods to study this problem is MALDI-TOF mass spectrometry (Matrix-Assisted Laser Desorption/Ionization Time-Of-Flight mass spectrometry). This method is successfully used to investigate biomolecules: aminoacids [16], peptides and proteins $[17,18]$, oligonucleotides and nucleic acids [19-22]. In particular, this approach allows studying their modification, the ways of fragmentation, the structure of covalent and non-covalent complexes, etc. MALDI-TOF method is applied even wider for fast and reliable determination of both nucleotide and aminoacid sequences, as well as for the identification of proteins in RNA-protein complexes [21-23]. For instance, mass spectrometry has been successfully employed to sequence oligoribonucleotides containing up to 22 nucleotides, and a number of proteins and peptide-RNA complexes in ribonucleoproteins [21, 24].

The analysis of mass spectrometry data ensures high accuracy of determining the molecular mass of the substance, the purity of the investigated sample and the identification of possible impurities. This method makes it possible to detect proteins in complex mixtures, to study the modification of biopolymers (glycosylation or phosphorylation of proteins, DNA methylation, etc.) $[18,22,23]$. The key feature of mass-spectrometric methods of analysis, including MALDI-TOF, the most significant for the current work, is broad possibilities of the study on non-covalent interaction in biopolymer complexes, e.g. protein-protein, protein-nucleic interactions, etc. [18, 22, 24-28].

An important stage in the determination of probable mechanisms of antiviral activity of oligoadenylates is investigation of the specificities of their interaction with target proteins participating in the antiviral protection of the cell, such as interferon. The current work is aimed at the in vitro study on binding of 6-interferon and insulin (a control protein that is not involved in the 2'-5'-OAS/RNAse L system) with a number of oligoadenylates of different structure using MALDI-TOF method.

Materials and Methods. 2'-5'-Triadenylate 2'-5'- $\mathrm{A}_{3}$ and its epoxy analogue 2'-5'- $\mathrm{A}_{3}$-epo were synthesized by [the] phosphotriester method in solution using 4-ethoxypyridine N-oxide [29] or N-methy- limidazole [30] as nucleophilic catalysts of coupling reactions.

Trimer 3'-5'-oligoadenylate 3'-5' $-\mathrm{A}_{3}$ was obtained by a standard solid-phase phosphoramidite method on ASM-800 synthesizer (Biosset, Russian Federation). 2'-5'- $\mathrm{A}_{3}$ : molecullar formula $\mathrm{C}_{30} \mathrm{H}_{37} \mathrm{~N}_{15} \mathrm{O}_{16} \mathrm{P}_{2}, \quad \mathrm{M}=$ 925.65, MALDI-mass-spectrum $-m / z=928.12$ $\left[(\mathrm{M}+\mathrm{H})^{+}\right], 792.18 \quad\left[(\mathrm{M}-\mathrm{Ade}+\mathrm{H})^{+}\right] ; 2^{\prime}-5^{\prime}-\mathrm{A}_{3}: \mathrm{C}_{30} \mathrm{H}_{37}$ $\mathrm{N}_{15} \mathrm{O}_{16} \mathrm{P}_{2}, \mathrm{M}=925.65, \mathrm{~m} / z=926.66\left[(\mathrm{M}+\mathrm{H})^{+}\right] ; 2^{\prime}-5^{\prime}-$ $\mathrm{A}_{3}$-epo: $\mathrm{C}_{30} \mathrm{H}_{35} \mathrm{~N}_{15} \mathrm{O}_{15} \mathrm{P}_{2}, \mathrm{M}=907.64, \mathrm{~m} / z=913.27$ $\left[(\mathrm{M}+\mathrm{H})^{+}\right]$.

Recombinant interferon $\alpha-2 b$ and human insulin were manufactured by Interpharmbiotek and Farmak companies (Ukraine), respectively.

Aqueous solutions of the samples were used. The solutions of proteins and oligonucleotides were incubated at $37{ }^{\circ} \mathrm{C}$ for $10 \mathrm{~min}$. The concentration of investigated compounds in the individual solutions and mixtures was $10^{-4} \mathrm{M}$ for all oligoadenylates, $10^{-5} \mathrm{M}$ for interferon, and $3.5 \cdot 10^{-5} \mathrm{M}$ for insulin.

Mass spectrometry analysis was conducted using MALDI-TOF spectrometer Voyager DE PRO (Applied Biosystems, USA). The accuracy of mass determination was $0.05 \%$, the measurements were performed in the $m / z$ range of $700-50,000$. The proteins and oligonucleotides were ionized using the sinapinic acid (Sigma-Aldrich, USA). The molecular mass was calculated by subtracting one from the $\mathrm{m} / \mathrm{z}$ value of a monovalent ion (proton mass $=1.007 \mathrm{Da}$ ). The instrument was calibrated using the calibration mixture calmix 3 from the manufacturer of the mass spectrometer. The matrix reagent was prepared by dissolving sinapinic acid $(10 \mathrm{mg} / \mathrm{ml})$ in the mixture of equal volumes of acetonitrile and $0.1 \%$ aqueous solution of trifluoroacetic acid (Sigma-Aldrich). 1.5-2 $\mu 1$ of the mixture of solutions of the investigated sample and reagent (1:1) was used for the application. A Linear working mode of the time-of-flight detector was used with the applied voltage of $25 \mathrm{kV}$, time delay of ion extraction was $500 \mathrm{~ns}$ [31].

The fluctuations in the molecular mass value for the same substance in different spectra can be explained by the change in the instrument resolution depending on the analysis parameters and incomplete reproducibility of peak geometry. 

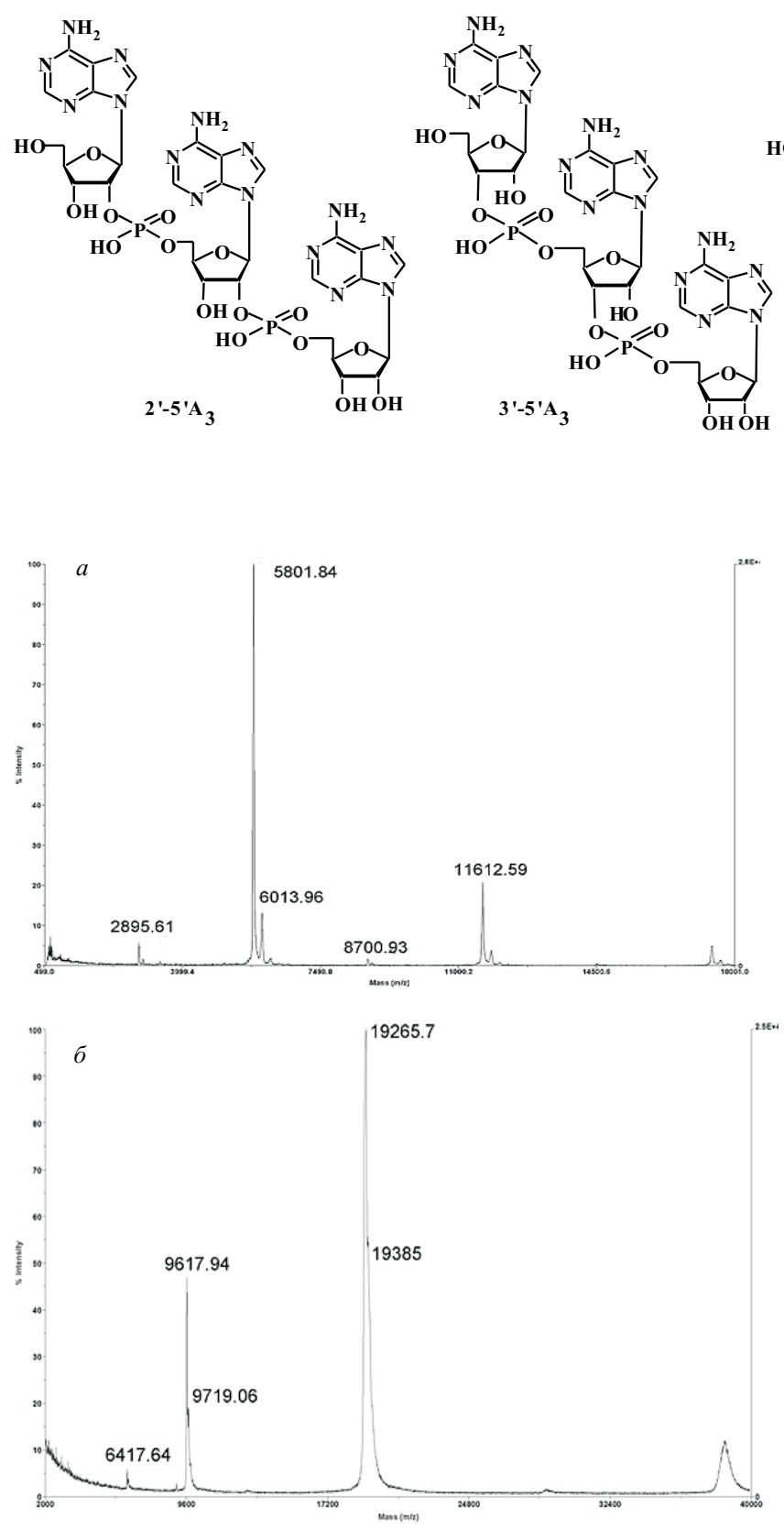

Fig. 2. MALDI mass spectra of insulin ( $a$ ) and $\alpha$-interferon $(b)$

The spectra were processed with Data Explorer 4.0 software (Applied Biosystems).

Results and Discussion. The method of MALDI-TOF mass spectrometry was used to study a number of short 2' -5 ' and 3'-5' -oligoadenylates as well as the proteins insulin and $\alpha$-interferon. Fig. 1 presents the structures of oligoadenylates. Mass spectra of the proteins are shown in Fig. 2.

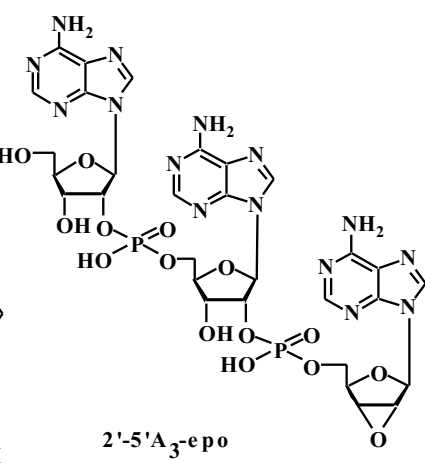

Fig. 1. Structures of investigated oligoadenylates

The first stage was investigation of the interaction of 2'-5'- $\mathrm{A}_{3}$ and a low-molecular protein - human insulin. The molecular mass obtained from the mass spectrum of insulin (Fig. 2, a) is 5,800.8 Da which is close to the theoretical value $(5,807.6 \mathrm{Da}$, error $0.12 \%)$ and is in good agreement with the data obtained in other works [26]. The peaks with $\mathrm{m} / z 11,613$ and 17,411 correspond to monocharged complexes containing two and three insulin molecules, respectively, (a proton is bound to the aggregate of two or three molecules), while the peak at 2,896 belongs to a dicharged (doubly protonated) insulin molecule. The peak with $\mathrm{m} / \mathrm{z}=$ 6,014 may correspond to the product of matrix-protein interaction: $\mathrm{m} / \mathrm{z}$ of one of the main peaks, corresponding to $(\mathrm{M}-\mathrm{OH})^{+}$fragment in the mass spectrum of sinapinic acid, is 207.07. The peaks in this region are also observed in the spectra of insulin mixtures with oligonucleotides.

The mass spectrum of insulin mixture with 2' -5 ' $-\mathrm{A}_{3}$ (Fig. 3, a) contains the peaks with $\mathrm{m} / \mathrm{z}$ values of 929.1 ; $2,908.6 ; 5,801.3 ; 11,649$ and 17,402 which correspond (within the limit of accuracy of the instrument) only to free components of the mixture (oligonucleotide and protein). Therefore, the interaction of insulin and 2 ' -5 ' $-\mathrm{A}_{3}$ was not registered in vitro.

The following series of experiments involved 6-interferon, widely used in the therapy of viral diseases such as hepatitis C. Fig. 2, $b$ presents the mass spectrum of $\alpha$-interferon, where the peak with $\mathrm{m} / \mathrm{z}=$ 19,265 corresponds to monocharged ion of the protein. The theoretical molecular mass of interferon $\alpha-2 b$ obtained from the amino acid sequence is 19,271 Da (DrugBank: http:// www.drugbank.ca/drugs/ DB00105), i.e. the deviation of the experimental value is $0.04 \%$. The peaks with $\mathrm{m} / \mathrm{z}$ values 9,618 and 6,417 

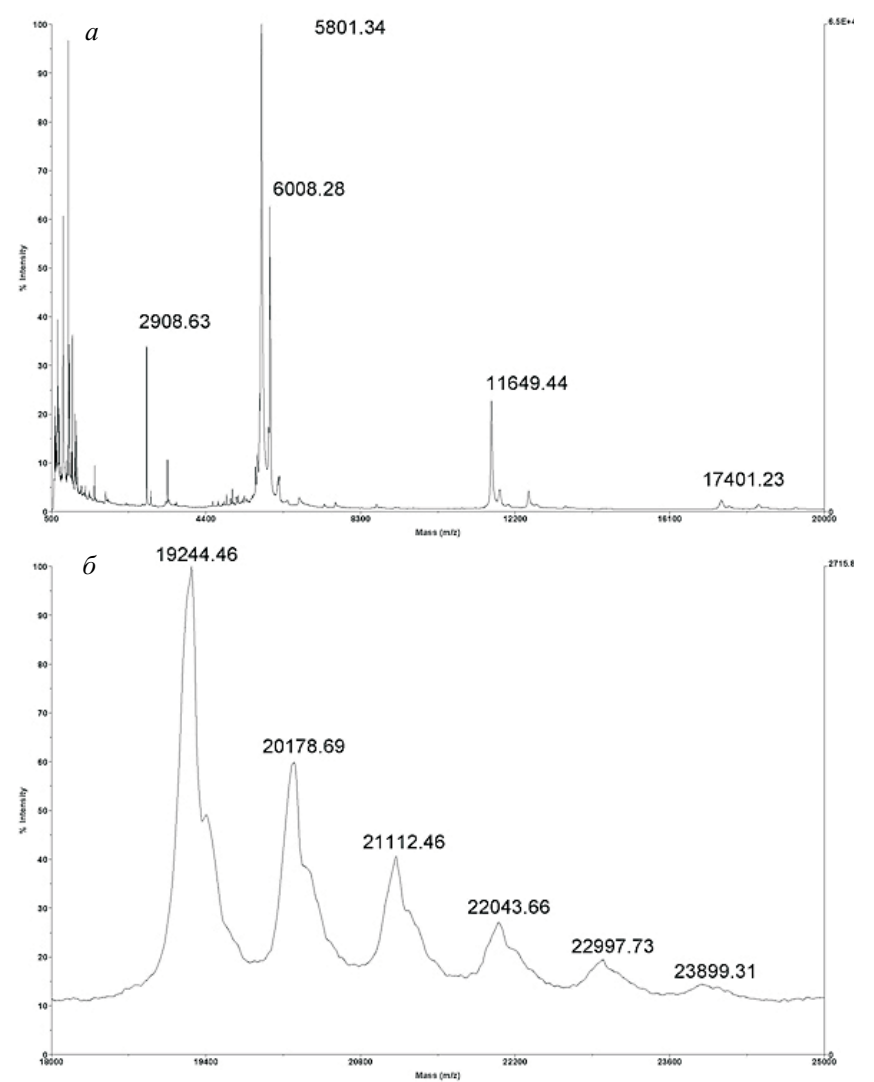

Fig. 3. MALDI mass spectra of the mixtures of insulin $(a)$ and $\alpha$-interferon (b) with oligoadenylate 2'-5'-A

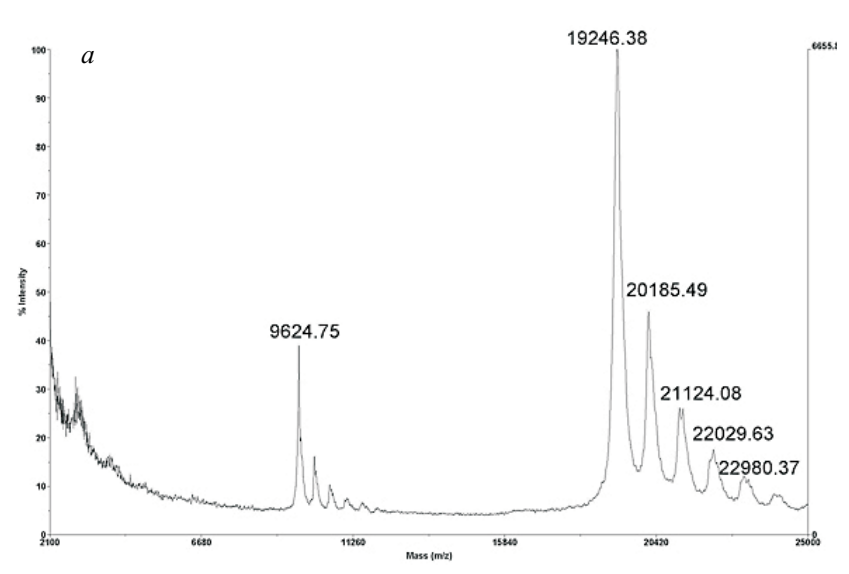

Fig. 4. MALDI mass spectrum of the mixture of $\alpha$-interferon and oligoadenylate 3 ' -5' - $\mathrm{A}_{3}$

belong to di- and tricharged ions of б-interferon $(\mathrm{m} / \mathrm{z}$ values are two and three times lower than that for monovalent ion, respectively). The peak with $\mathrm{m} / \mathrm{z}$ value of 38,610 corresponds to monoprotonated complex of two interferon molecules. The mass spectrometry data obtained for 6-interferon by us are in good agreement with the literature $[32,33]$.

Fig. $3, b$ presents the fragment of the spectrum of the mixture of interferon and 2'-5'- $\mathrm{A}_{3}$ which demonstrates the formation of protein complexes with one or several oligonucleotide molecules. Contrary to the insulin -2 ' -5 ' $-\mathrm{A}_{3}$ mixture whose spectrum contains only peaks belonging to its components, the addition of 2 ' -5 ' $-\mathrm{A}_{3}$ to interferon led to considerable changes in the mass spectrum. In particular, the peaks with $\mathrm{m} / \mathrm{z}$ values $20,179,21,112,22,044,22,998$ and 23,899 appear in the spectrum of interferon-2'-5'-A $\mathrm{A}_{3}$ system. They correspond to the complexes composed of one interferon molecule and one to five 2'-5'- $\mathrm{A}_{3}$ molecules. The obtained molecular mass values are in good agreement with theoretical ones. Thus, the deviation of experimental $\mathrm{m} / \mathrm{z}$ from the theoretically calculated value for protein complexes with one or two $2^{\prime}-5^{\prime}-\mathrm{A}_{3}$ molecules is 0.09 and $0.06 \%$, respectively.

As the complexes are detected after the impact of laser ionization, their registration in mass spectra suggests rather strong interaction between the molecules of protein and oligoadenylate. It should be noted that the formation of protein complex with several ligand molecules is more difficult as compared to the complex with a single ligand; it also decomposes at the ionization step (before registration by the instrument) more easily. Therefore, the formation of stable multiple aggregates confirms quite strong binding of $\alpha$-interferon to the ligand.

At the next stage we studied the interaction of 6-interferon with a natural 3'-5'-triadenylate which differs from 2'-5'- $\mathrm{A}_{3}$ only by the type of internucleotide bonds. The mass spectrum of insulin and 3'-5'-A mixture (Fig. 4) registers multiple interaction of a protein molecule with one or several molecules of oligonucleotide. Similar to $2^{\prime}-5^{\prime}-\mathrm{A}_{3}$, the formation of stable complexes containing one to five molecules of triadenylate per protein molecule was detected. The spectrum of the mixture also contains a group of less intense peaks corresponding to doubly protonated complexes (in the range of $m / z 9,600-11,300$ ).

3'-Epoxy-modified oligoadenylate 2'-5'-A was selected for further experiments. As shown in previous works of many authors, even a slight 

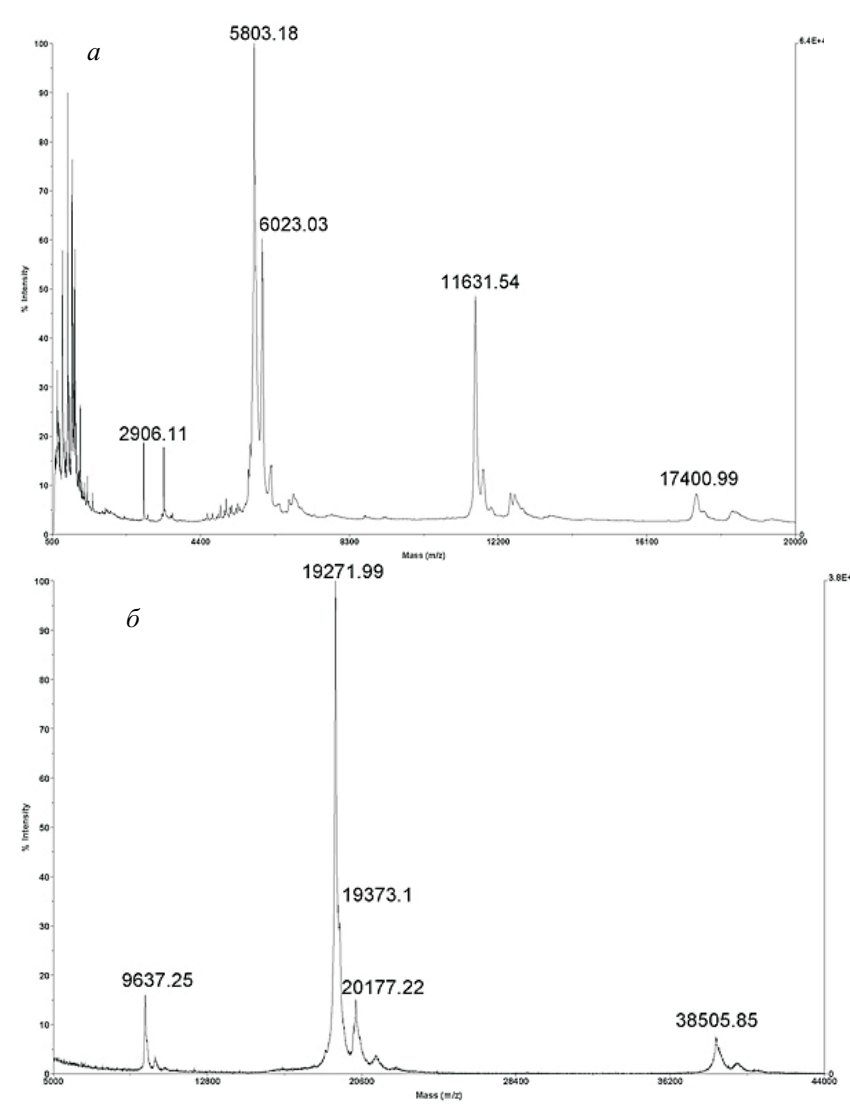

Fig. 5. MALDI mass spectra of the mixtures of insulin $(a)$ and $\alpha$-interferon $(b)$ with oligoadenylate 2 ' - 5 ' - $\mathrm{A}_{3}$-epo

modification of the 2-5A structure may result in sharp changes in its biological activity $[1,3,5,6]$. The above mentioned analogue of 2'-5'-triadenylate also demonstrates interesting and diverse biological activity $[30,34-36]$.

The mass spectrum of the mixture of insulin and 2'-5'-A - A $_{3}$-epo consists only of the peaks of oligonucleotide and protein (Fig. 5,a). No additional peaks were registered, i.e. the mass spectrum of the mixture is actually the superposition of the spectra of its components. The peak with $\mathrm{m} / \mathrm{z}=6,023$ may be the product of sinapinic acid binding to the protein $(\mathrm{M}=$ 224.21). Therefore, as in the case of non-modified trimers, no interaction of $2^{\prime}-5^{\prime}-\mathrm{A}_{3}$ analogue with insulin was registered in vitro.

The mass spectrum of the 6-interferon mixture with 2'-5'-A -epo (Fig. 5, $b$ ) contains a new peak with $\mathrm{m} / \mathrm{z}=$ 20,177 which suggests the binding of 6 -interferon to 2'-5'-A - -epo molecule (the deviation from the theo- retical value of molecular mass of the complex is 0.06 $\%)$. There are also two less intense peaks in the spectrum corresponding to the complexes of the interferon molecule and two and three molecules of oligonucleotide. Thus, 2'-5' - $\mathrm{A}_{3}$-epo also binds to interferon.

It is commonly assumed that antiviral properties of phosphorylated 2-5A are related to their capability of activating RNAse $\mathrm{L}$, which, in turn, destroys viral mRNA [1, 8-11, 37-39]. However, "core" 2-5A and their analogues are remarkable also for other properties which cannot be explained by the abovementioned mechanism. In particular, these properties include the prevention of tissue rejection after transplantation, the effect on proliferation and apoptosis of stem cells, cardioprotecting properties, etc. [30, 34, 35].

Therefore, new approaches should be elaborated which would allow determining the mechanisms for unusual biological activities of "core" oligoadenylates. One of possible explanations may be the ability of oligoadenylates to interact with some proteins that determines their biological activity.

In our previous research the method of fluorescent spectroscopy was used to demonstrate the interaction of 2'-5'-oligoadenylates and a number of their analogues with albumin and interferon, with no binding to immunoglobulin $G$ [36]. The results of numerous studies on the mechanisms of antiviral activity of 2-5A suggest its direct relation to the activity of interferon [1, $3,8-10,38,39]$. The analysis of oligoadenylate-inter feron systems performed using the mass spectrometry method allowed us to discover rather stable interactions between this protein and oligonucleotides. It should be noted that the mass spectra of mixtures incubated for 24 hours at $4{ }^{\circ} \mathrm{C}$ were identical to those obtained after 10 min of incubation at $37{ }^{\circ} \mathrm{C}$.

Conclusions. Our work presents the first study on the interaction of oligonucleotides and proteins in vitro by MALDI-TOF method.

It was shown that under the applied experimental conditions the natural $2^{\prime}-5^{\prime}-\mathrm{A}_{3}$, its epoxy analogue 2'-5'-A -epo and 3'-5'-triadenylate are not capable of binding to insulin. At the same time, all the investigated 2'-5' and 3'-5'-oligoadenylates can bind to 6-interferon, which is involved in 2'-5'-OAS/RNAse L system, in the ratio of one to five molecules of the ligand per protein molecule, to form stable complexes. 
С. М. Левченко ${ }^{1}$, А. В. Ребрієв , В. В. Ткачук', Л. В. Дубей I. Я. Дубей' , 3. Ю. Ткачук ${ }^{I}$

Дослідження взаємодії олігоаденілатів з білками in vitro методом мас-спектрометрії MALDI-TOF

${ }^{1}$ Інститут молекулярної біології і генетики НАН України Вул. Академіка Заболотного, 150, Київ, Україна, 03680

${ }^{2}$ Інститут біохімії ім. О. В. Палладіна НАН України Вул. Леонтовича, 9, Київ, Україна, 01601

Резюме

Мета. Дослідити здатність «корових» 2'-5'- $і$ 3'-5'-олігоаденілатів взаємодіяти з $\alpha$-інтерфероном - ключовим білком системи 2'-5'-ОАС/РНКаза L, відповідальної за противірусний захист клітини. Методи. Для вивчення взаємодій білок-олігонуклеотид використано метод мас-спектрометрії MALDI-TOF. Peзультати. Встановлено здатність 2'-5'- $A_{3}$ та його епоксимодифікованого аналога 2'-5'- $A_{3}$-еро зв'язуватися з $\alpha$-інтерфероном in vitro. 3 иим білком може також взаємодіяти і 3'-5'-триаденілат. При иьому до молекули $\alpha$-інтерферону одночасно може приєднуватися від однієї до п'яти молекул ліганду. У той же час з інсуліном усі досліджені олігонуклеотиди не зв 'язуються. Висновки. Показано, що «корові» 2'-5'- $i$ 3'-5'-триаденілати множинно взаємодіють з $\alpha$-інтерфероном з утворенням стійких комплексів. Однак вони не зв 'язуються з інсуліном, який не є компонентом системи 2'-5'-OAC/PНКаза L.

Ключові слова: олігоаденілати, інсулін, $\alpha$-інтерферон, мас-спектрометрія MALDI-TOF.

С. М. Левченко, А. В. Ребриев, В. В. Ткачук, Л. В. Дубей, И. Я. Дубей, 3. Ю. Ткачук

Исследование взаимодействия олигоаденилатов с белками in vitro методом масс-спектрометрии MALDI-TOF

Резюме

Цель. Исследовать способность «коровых» 2'-5'- и 3'-5'-олигоаденилатов взаимодействовать $c$-интерфероном - ключевым белком системь 2'-5'-OAC/PHКаза L, ответственной за противовирусную защиту клетки. Методы. Для изучения взаимодействий белок-олигонуклеотид использован метод масс-спектрометрии MALDI-TOF. Результаты. Установлена способность 2'-5'- $A_{3}$ и его эпокси-модифицированного аналога $2^{\prime}-5$ '- $A_{3}$-еро связываться с $\alpha$-интерфероном іn vitro. $C$ этим белком может также взаимодействовать и 3'-5'-триаденилат. При этом к молекуле $\alpha$-интерферона одновременно может присоединяться от одной до пяти молекул лиганда. В то же время с инсулином все изученные олигонуклеотиды не связываются. Выводы. Показано, что «коровые» 2'-5'- и 3'-5'-триаденилаты способны к множественному взаимодействию с $\alpha$-интерфероном с образованием устойчивых комплексов. Однако они не связываются с инсулином, не являющемся компонентом системь 2'-5'-OAC/РНКаза L.

Ключевые слова: олигоаденилаты, инсулин, $\alpha$-интерферон, масс-спектрометрия MALDI-TOF.

\section{REFERENCES}

1. Player M. R., Torrence P. F. The 2-5A system: modulation of vi$\mathrm{ral}$ and cellular processes through acceleration of RNA degradation // Pharmacol. Ther.-1998.-78, N 2.-P. 55-113.

2. Morin B., Rabah N., Boretto-Soler J., Tolou H., Alvarez K., Canard B. High yield synthesis, purification and characterisation of the RNase $\mathrm{L}$ activators 5'-triphosphate 2'-5'-oligoadenylates // Antiviral Res.-2010.-87, N 3.-P. 345-352.

3. Nagaoka K., Kitamura Y., Ueno Y., Kitade Y. 5'-O-dephosphorylated 2',5'-oligoadenylate (2-5A) with 8-methyladenosine at the 2'-terminus activates human RNase L // Bioorg. Med. Chem. Lett.-2010.-20, N 3.-P. 1186-1188.

4. Lopp A., Reintamm T., Kuusksalu A., Tammiste I., Pihlak A., Kelve M. Natural occurrence of 2',5'-linked heteronucleotides in marine sponges // Mar. Drugs.-2010.-8, N 2.-P. 235-254.

5. Kiuru E., Ora M., Beigelman L., Blatt L., Lonnberg H. Synthesis and enzymatic deprotection of fully protected 2'-5' oligoadenylates (2-5A): towards a prodrug strategy for short 2-5A // Chem. Biodivers.-2012.-9, N 4.-P. 669-688.

6. Wang X., Tian H., Lee Z., Heston W. D. Structure-activity relationships of 2',5'-oligoadenylate analogue modifications of prostate-specific membrane antigen (PSMA) antagonists // Nucleosides Nucleotides Nucleic Acids.-2012.-31, N 5.-P. 432-444.

7. Tanaka N., Nakanishi M., Kusakabe Y., Goto Y., Kitade Y., Nakamura K. T. Structural basis for recognition of 2'-5'-linked oligoadenylats by human ribonuclease L // EMBO J.-2004.-23, N 20.P. 3929-3938.

8. Tsai S. C. Biomacromolecules. Introduction to structure, function and informatics.-New Jersey: Willey-Liss, 2007.-740 p.

9. Silverman $R$. $H$. A scientific journey through the $2-5 \mathrm{~A} / \mathrm{RNase} \mathrm{L}$ system // Cytokine Growth Factor Rev.-2007.-18, N 5-6.P. 381-388.

10. Kristiansen H., Gad H. H., Eskildsen-Larsen S., Despres P., Hartmann $R$. The oligoadenylate synthetase family: an ancient protein family with multiple antiviral activities // J. Interferon Cytokine Res.-2011.-31, N 1.-P. 41-47.

11. Chakrabarti A., Ghosh P. K., Banerjee S., Gaughan C., Silverman $R$. $H$. RNase $\mathrm{L}$ triggers autophagy in response to viral infections // J. Virol.-2012.-86, N 20.-P. 11311-11321.

12. Clemens M. J., Vaquero C. M. Inhibitor of protein synthesis by double-stranded RNA in reticulocyte lysates: evidence for activation of an endoribonuclease // Biochem. Biophys. Res. Commun.-1978.-83, N 1.-P. 59-68.

13. Meuers E., Chong K., Galabru J., Thomas N. S., Kerr I. M., William B. R., Hovanessian A. G. Molecular cloning and characterization of the human double-stranded RNA-activated protein kinase induced by interferon // Cell.-1990.-62, N 2.-P. 379-390.

14. Pavlovic J., Staeheli P. The antiviral potentials of Mx proteins // J. Interferon Res.-1991.-11, N 4.-P. 215-219.

15. Malathi K., Saito T., Crochet N., Barton D. J., Gale M. Jr., Silverman $R$. $H$. RNase $\mathrm{L}$ releases a small RNA from HCV RNA that refolds into a potent PAMP // RNA.-2010.-16, N 11.-P. 2108 2119.

16. Gogichaeva N. V., Williams T., Alterman M. A. MALDI-TOF tandem mass spectrometry as a new toll for amino acid analysis // J. Am. Soc. Mass Spectrom.-2007.-18, N 2.-P. 279-284.

17. McIver R. T. Jr., Li Y., Hunter R. L. High-resolution laser desorption mass spectrometry of peptides and small proteins // Proc. Natl Acad. Sci. USA.-1994.-91, N 11.-P. 4801-4805.

18. Mass spectrometry of proteins and peptides / Ed. Chapman J. R.-Totowa: Humana Press, 2000.-544 p.

19. Hettich R., Buchanan M. Structural characterization of normal and modified oligonucleotides by matrix-assisted laser desorp- 
tion fourier transform mass spectrometry // J. Am. Soc. Mass Spectrom.-1991.-2, N 5.-P. 402-412.

20. Kuusksalu A., Subbi J., Pehk T., Reintamm T., Muller W. E., Kelve $M$. Identification of the reaction products of $\left(2^{\prime}-5^{\prime}\right)$ oligoadenylate synthetase in the marine sponge // Eur. J. Biochem.-1998.-257, N 2.-P. 420-426.

21. Faulstich K., Worner K., Brill H., Engels J. W. A sequencing method for RNA oligonucleotides based on mass spectrometry // Anal. Chem.-1997.-69, N 21.-P. 4349-4353.

22. Banoub J. H., Newton R. P., Esmans E., Ewing D.E., Mackenzie $G$. Recent developments in mass spectrometry for the characterization of nucleosides, nucleotides, oligonucleotides, and nucleic acids // Chem. Rev.-2005.-105, N 5.-P. 1869-1915.

23. Liebler D. C. Introduction to proteomics: tools for the new biology.-Totowa: Humana Press, 2002.-198 p.

24. Kuhn-Holsken E., Lenz C., Sander B., Luhrmann R., Urlaub H. Complete MALDI-Tof MS analysis of cross-linked peptideRNA oligonucleotides derived from nonlabeled UV-irradiated ribonucleoprotein // RNA.-2005.-11, N 12.-P. 1915-1930.

25. Tang X., Callahan J. H., Zhou P., Vertes A. Noncovalent proteinoligonucleotide interactions monitored by matrix-assisted laser desorption/ionization mass spectrometry // Anal. Chem.-1995.67, N 24.-P. 4542-4548.

26. Salih B. Determination of high molecular weight biomolecules and their non-covalent complexes in MALDI-TOF-MS $/ / 4^{\text {th }}$ AACD Congress (29 Sept.-3 Oct. 2004, Aydin, Turkey): Proceedings Book.-Aydin, 2004.-P. 352-354.

27. Luo Y., Li T., Yu F., Kramer T., Cristea I. M. Resolving the composition of protein complexes using a MALDI LTQ Orbitrap // J. Am. Soc. Mass Spectrom.-2010.-21, N 1.-P. 34-46.

28. Chiang C. K., Yang Z., Lin Y. W., Chen W. T., Lin H. J., Chang H. T. Detection of proteins and protein-ligand complexes using $\mathrm{HgTe}$ nanostructure matrixes in surface-assisted laser desorption/ionization mass spectrometry // Anal. Chem.-2010.-82, N 11.-P. 4543-4550.

29. Dubey I. Ya., Dubey L. V. Synthesis of (2'-5')-triadenylates and their analogues using O-nucleophilic catalysis of internucleotide coupling reaction // Biopolym. Cell.-2007.-23, N 6.P. 538-544.

30. Tkachuk Z. Yu., Dubey I. Ya., Yakovenko T. G., Semernikova L. I., Shapoval S. O., Artemenko V. S., Dubey L. V. Synthesis of 2'5 '-oligoadenylates and study of their effect on proliferation and migration of bone marrow stem cells of mice in vitro and in vivo // Biopolym. Cell.-2007.-23, N 1.-P. 14-20.

31. Voyager $^{\mathrm{TM}}$ Biospectrometry $^{\mathrm{TM}}$ workstation with delayed Extraction $^{\circledR}$ technology. User guide, version 5.1// Foster City: Applied Biosystems, 2001.-P. 738.

32. Zhou G. H., Luo G. A., Sun G.-Q., Cao Y. C., Zhu M. S. Study on the quality of recombinant proteins using matrix-assisted laser desorption ionization time of flight mass spectrometry // World J. Gastroenterol.-1999.-5, N 3.-P. 235-240.

33. Pokholenko Ya. A., Porubleva L. V., Dubey I. Ya., Rebriev A. V., Sutugina L. P., Gromovoy T. Yu., Pokrovskiy V. O., Obolenskaya M. Yu., Chernykh S. I. Obtaining and characteristics of national preparation interferon $\alpha-2 b$ with prolonged effect // Ukr. Biochem. J.-2008.-80, N 6.-P. 92-100.

34. Sidorik L. L., Dubey I. Ya., Bobyk V. I., Kozlov A. V., Fedorkova O. M., Kovenya T. V., Ryabenko D. V., Sergienko O. V., Trunina I. V., Pogrebnoy P. V., Matsuka G. H. Therapeutic effects of various doses of 2'-5'-oligoadenylates in experimental myosin-induced myocardial damage // Dop. NAN Ukrainy.-2001.-N 9.P. 161-165.

35. Filippov I. B., TkachukZ. Yu., Dubey I. Ya. Mechanisms of vessel tone regulation by 2'-5'-oligoadenylates // Dop. NAN Ukrainy.2010.-N 6.-P. 152-157.

36. Tkachuk Z. Yu., Dubey L. V., Tkachuk V. V., Tkachuk L. V., Losytskyy M. Yu., YashchukV.M., Dubey I. Ya. Studying the interaction of 2'-5'-oligoadenylates and their analogues with proteins by fluorescence spectroscopy // Ukr. Biochem. J.-2011.-83, N 1.-P. 45-53.

37. Silverman R. H. Viral encounters with 2'-5'-oligoadenylate synthetase and RNase L during the interferon antiviral response // J. Virol.-2007.-81, N 23.-P. 12720-12729.

38. Chakrabarti A., Jha B., Silverman R. H. New insights into the role of RNase L in innate immunity // J. Interferon Cytokine Res.2011.-31, N 1.-P. 49-57.

39. Anderson B. R., Muramatsu H., Jha B. K., Silverman R. H., Weissman D., Kariko K. Nucleoside modifications in RNA limit activation of 2'-5'-oligoadenylate synthetase and increase resistance to cleavage by RNase L // Nucleic Acids Res.-2011.-39, N 21.P. 9329-9338. 